\title{
Os Pensadores e a Ciência da Informação
}

\author{
SANTAREM SEGUNDO, J. E., SILVA, M. R., MOSTAFA, S. P. (Orgs). Os pensadores e a \\ ciência da informação. Rio de Janeiro: E-Papers, 2012.
}

Esta resenha é a apresentação do livro "Os pensadores e a Ciência da Informação", publicado pela Editora E-Papers em 2012, organizado pelos professores: José Eduardo Santarem Segundo, Márcia Regina da Silva e Solange Puntel Mostafa, todos do curso de Ciências da Informação e da Documentação, da USP de Ribeirão Preto.

O leitor tem acesso à versão impressa e digital (e-book) diretamente no site da editora pelo endereço: http://www.e-papers.com.br/produtos.asp?codigo_produto=2229.

A conjunção "e" na Ciência da Informação foi o primeiro título vislumbrado para este livro. Entretanto, ao escrevê-lo, fomos chamando-o O livro dos pensadores. Agora, ao apresentá-lo aos leitores, desejamos chamá-lo Os pensadores e a Ciência da Informação.

Apresentamos o pensamento de alguns clássicos em sua relação com a Ciência da Informação. São eles filósofos, sociólogos, historiadores, estudiosos da cultura, linguistas e informatas. O leitor terá acesso à pequena biografia e obra de cada um e, mais importante, à maneira como cada pesquisador deste livro se apropria das ideias do biografado para suas próprias pesquisas em Ciência da Informação. Essa é a grande novidade: os cientistas da informação deste volume, em sua maioria docentes do Curso de Ciências da Informação e Documentação da USP-Ribeirão Preto (SP), aceitam o desafio da conjunção "e" e nela se exercitam.

A conjunção "e" merece a atenção de todos nós, pois é através dela que podemos conectar os elementos mais diversos em um conjunto. Se chamarmos tal conjunto de rizoma, como fizeram alguns filósofos, a conjunção "e" será o tecido de tal rizoma, um tecido muito potente, cujos fios constroem pontes, passagens e novas paisagens, fazendo do conjunto um sistema aberto. Tal abertura dá à conjunção " $e$ " a força de desestabilizar verbos e atribuições, uma vez que a conjunção não é atributiva, apenas conectiva, com valor de mais um... Sempre é possível uma nova conexão. E essa dará ensejo a mais uma.

Mas o esforço em conectar exige, quiçá, uma atenção diferente daquela a que estamos acostumados, pois se tratam de encontros. E há qualquer coisa de imponderável nos encontros, porque eles se fazem sem muita intencionalidade. Os encontros acontecem... Os 
encontros são involuntários...

Os autores deste livro se encontram involuntariamente e, afetados por este encontro, produzem todo tipo de linha para a viagem do leitor. Pois estamos neste livro ligados por conjunções disjuntivas, isto é, ligados por alternativas que não se excluem, tal a disjunção de nossa conjunção "e": a não relação da disjunção torna-se uma relação para nós. Assim são as relações e a lógica própria do rizoma: nosso "e" liga e desliga para tornar possível o aparecimento de novas ligações, como convém às topologias das redes. Praticamos uma lógica nomeada, por isso, de lógica da síntese disjuntiva, entendendo que toda conjunção é uma disjunção. Em vez de formas usuais de juntar, como "ou... ou”, "nem... nem”, preferimos algo como "e... e... e". Nas conjunções encontramos as ligações; nos intervalos, as disjunções; tal como uma colcha de retalhos, vamos construindo, neste livro, encontros pelas bordas que se traduzem em experiências informacionais, que esperamos serem ricas para o leitor de Ciência da Informação.

Assim, iniciamos nossa viagem com Pierre Bourdieu, a Bibliometria e a comunicação científica. Pertinho dali, Roger Chartier quer nos falar sobre novos processos de leitura e quisemos relacioná-los a uma nova biblioteca escolar. Nova também é a proposta de Robert Darnton para os estudos bibliográficos, uma proposta mais documental. Ludwig Wittgenstein é apresentado aos leitores como um atiçador para a Ciência da Informação. E o que dizer de Michel (Pêcheux) e este outro arquivo que nos apresenta?

Outra leitura, outra bibliografia, outro arquivo?! Latour nos falará, pasmem, de um outro social, e Tim Berners Lee, de uma outra Web, mais semântica!

Parece, então, que um outro mundo é possível para a Ciência da Informação? Sim, Gilles Deleuze toma a palavra no final do livro para dizer que vários outros mundos são possíveis, basta que saibamos exercitar a conjunção "e", "e... e". Com o leitor, Os pensadores e a Ciência da Informação.

Os organizadores

Resenha enviada em: 20 abr. 2012

InCID: R. Ci. Inf. e Doc., Ribeirão Preto, v. 3, n. 1, p. 182-183, jan./jun. 2012. 